\title{
ANALYSIS OF METHODS OF PROJECT MANAGEMENT IN ASPECT OF SECURITY
}

\author{
S.A. Bogatenkov1, ser-bogatenkov@yandex.ru, \\ Ya.D.Gel'rud', gelrud@mail.ru, \\ D.S. Bogatenkov², mr.bogatenkov@gmail.com \\ ${ }^{1}$ South Ural State University, Chelyabinsk, Russian Federation, \\ ${ }^{2}$ Chelyabinsk State University, Chelyabinsk, Russian Federation
}

Modern information society is characterized by intensive penetration of information technology (IT) in all spheres of life. Modern socio-economic systems are in constant evolution, increasing their complexity and number of indicators required for analysis. The problem of technogenic energy security $70 \%$ associated with the human factor. Modern information society is characterized by increased risks. Damages from technological disasters, accidents commensurate with the annual GDP growth. Information-analytical system of project management based on complex mathematical models of the functioning of the stakeholders allows minimizing the social risks as a result of consideration of the interests of functioning of the parties. However, for successful implementation of the project to implement the information-analytical system in the modern information society it is necessary to evaluate further the didactic risks associated with the training of stakeholders, i.e. with the formation of the corresponding competences, taking into account their basic education and work experience. The increase in the number of indicators of socio-economic systems and the role of the human factor leads to increasing damage and number of unsuccessful projects. Based on the review of the project management concluded that the need for a systematic approach to the impact of risks. First, for the implementation of methods that minimizes economic risks in connection with the registration and processing of a large amount of input information necessary to evaluate the risks of the implementation of information-measuring systems. Secondly, the implementation of informationanalytical systems and compensation plans to reduce social risks, it is necessary to consider the risks, considering the dynamics of the development of enterprises. Thirdly, to implement the method of management of educational trajectories on the basis of classification of competences, allowing minimizing the didactic risks, it is necessary to consider the risks based on the experience of the staff.

Keywords: project management, methods, safety, risk.

\section{Introduction}

Modern information society is characterized by intensive penetration of information technology (IT) in all spheres of life. For example, the global industry e-learning at the beginning of this century amounted to $\$ 48$ billion [1]. The main goals stipulated in the programme of development of the digital economy in Russia to 2024, include: providing fast Internet access for every citizen of Russia, including inhabitants of remote settlements; replacement of high school diplomas and work books on the path of development, "smart cities" and even an automated system of decision-making [2].

Modern socio-economic systems are in constant evolution, increasing their complexity and number of indicators required for analysis. The problem of technogenic energy security $70 \%$ associated with the human factor [3].

The increase in the number of indicators of socio-economic systems and the role of the human factor leads to increasing damage and number of unsuccessful projects.

Modern information society is characterized by increased risks. Damages from technological disasters, accidents commensurate with the annual GDP growth [3].

According to experts of the American Institute of project management (Project Management Institute PMI), irreparable losses of organizations due to the low quality of project management constitute per billion of US \$ 109 million. USA [4]. A similar pattern is observed with the execution of complex and mega projects in Russia. Therefore, project management in practice implementing no more than half of its capacity.

Failures of project activities due to the need to reduce:

- economic risks associated with the registration and processing of a large volume of input information in conditions of uncertainty $[5,6]$;

- social risks associated with the lack of effective staff motivation system, taking into account the interests of the functioning of the parties [7] and the dynamics of development of enterprises [8]; 
- didactic risks due to the increasing number of students with various levels of basic education in connection with the development of distance learning technologies [9].

For the analysis of methods of project management in the information society, consider the following methods:

1. The methods of principal components and of the eigenstates in the tasks of analysis and forecasting of socio-economic systems, allowing minimizing the economic, educational and environmental risks [5].

2. The mathematical method of monitoring the reliability of the measuring information about the flow of energy resources on the basis of the theory of state estimation [6], which allows to reduce the complexity and time spent by personnel in hazardous areas to perform work on technical diagnostics of measuring channels, i.e. minimizing economic and environmental risks

3. Personnel management of commercial enterprises based on process modeling of network marketing [12], which allows to compensate the work, i.e., to minimize social risks.

4. Information-analytical system of project management based on complex mathematical models of the functioning of the stakeholders [10] allows minimizing the social risks as a result of consideration of the interests of functioning of the parties.

5. Management of educational trajectories on the basis of the classification of competences [9], allowing to minimize risks of didactic

\section{The methods of principal components and of the eigenstates in the tasks of analysis and forecasting of socio-economic systems}

Necessary condition for existing methods of mathematical modeling is the requirement, according to which the number of observations should be two to three times the number of variables, so it is quite difficult for modern socio-economic systems to collect data from a large number of observations.

A promising direction to reduce the number of observations is the construction of models based on individual indicators, and their combinations. These combinations can be interpreted as certain images or their own state system. Building models is the selection key of the eigenstates of the system, focused on success factors and demonstrating the causal interactions associated with the strategic nature of the changes of socio-economic systems.

To solve such problems it is necessary to apply technologies to establish and measure causal relationships between different processes in socio-economic systems. One such technology is the method of principal components, which allows to operate not only with individual parameters, and their combinations. One of the advantages of this approach is that it allows representing the behavior of the socioeconomic system as a set of independent components, each of which can be analyzed separately. The development of the method of principal components as applied to analysis and forecasting of socioeconomic systems allowed us to formulate a new method, called the method's own state.

Application of methods of principal components and of their own States gave the opportunity to carry out the forecast indicators of the development of the city of Chelyabinsk till 2020 on the basis of the concept of sustainable development. Analysis of the results shows that the town is developed in accordance with the concept of sustainable development the following subsystems: "Business", "Budget", "Investment", "housing and construction", "the standard of living of the population."

Optimistic forecast of the city's sustainable development in these subsystems due to:

- The availability of adequate human resources;

- Stable development of the industrial potential of the urban areas;

- Steady growth in residential construction.

Poor prognosis for subsystems "Environment", "Education and health", "Transport and communication" due to the negative trends, destabilizing development of the city. Among them:

- underdeveloped social infrastructure;

- unstable rate of decline in emissions of industrial enterprises;

- an avalanche and uncontrollable increase in the number of cars and the routing of vehicles while conducting degradation of public transport.

The prognosis helped to identify the environmental, economic, and educational risks for the sustainable economic development of the city of Chelyabinsk [5].

However, the implementation of the project for implementation of this method must also assess the risks associated with the introduction of the automated system for the collection and processing of baseline data under conditions of uncertainty. 


\section{Управление в социально-экономических системах}

The mathematical method of monitoring the reliability of the measuring information about the flow of energy resources on the basis of the theory of state estimation

Crashes and injuries in measurement and information part of the automated information-measuring system of control and metering of energy resources (AIMS CMER) can distort the commercial measurement of energy resources (ER) and lead to financial risk of the power supplying organizations. In addition, the errors in the measurements can be associated with the deliberate distortion of the measurements to reduce fees for the use of ER from the consumer, which leads to commercial losses ER.

The mathematical method of monitoring the reliability of the measuring information based on the theory of state estimation is focused on the transport network ER such as electrical and thermal energy, oil, gas, etc. Transport network the energy source is represented as a graph, whose nodes are producers and consumers, and the branches - highways (transmission lines, pipelines and elements of heat networks).

The basic idea of state estimation is obtaining analogs of ER calculated for all available measurements. In contrast to the "raw" measurements that contain error, the estimated flows of ER, called estimated that will fully meet the condition of fitness for all equations of state that describe the transportation network of the ER. The equation of state, recorded using the estimated parameters won't contain the residuals. The difference between the measured and calculated analog (rating) in the theory of estimation is called the residual evaluation. The obtained large values of the residues assessment are indicative of high errors with specific measurements ER.

This method allows increasing the reliability of measurements of ER, to assess the observability of the transport network, to eliminate the unbalance measuring fluxes of ER and perform filtering of false measurements at the stage of collecting and processing information [6].

A method of monitoring the reliability of the measuring information based on the theory of state estimation can reduce the complexity and time spent by personnel in hazardous areas to perform work on technical diagnostics of measuring channels, i.e., to minimize economic and environmental risks.

However, the implementation of the project for implementation of this method must also assess the risks associated with the implementation and maintenance of the AIMS CMER that provides the source information for this method or to create high-tech systems for the new generation of measuring and recording ER in the face of uncertainty caused by errors of measuring channels.

\section{Personnel management of commercial enterprises based on process modeling} of network marketing

A necessary condition for the success of projects is the use of effective methods of personnel motivation.

One of the ways to improve the efficiency of business processes in network marketing is to develop methods of effective management of business processes based on mathematical models that take into account the economic dynamics of the development of networked enterprises [9].

To this model belongs the compensation plan.

When developing compensation plans network businesses (NB) takes into account the dynamics of their development that includes four stages.

Base - this stage lasts approximately 6 months. The company develops the product and compensation plan.

Concentration - this period lasts from 1 to 3 years. Formed distribution network. Most of the new network of companies "fall apart" it is at this stage.

Inertia - this period also lasts from 1 to 3 years. This is a time of rapid company growth. And sales and the growth of distribution companies increase their volumes and distribution. During this period the company effectively "sweeps" the population.

Stabilization - the period lasts for the rest of the life of the company. Those network companies that care about the success of their distributors are long-lived, and it is a guarantee that the distribution network will continue to grow and bring a good income.

It is also vital to consider the relations between the NB and distributors, because it and the structure of the NB. The document, which is regulating the internal relations of the NB system it distributors is a compensation plan or marketing plan, or a payment plan, developed by the NB. Compensation plan includes the following elements of an organization's activities: 
- a contract entered into with the distributor;

- pricing policy of the company in relation to distributors and customers;

- the system rewards distributors;

- conditions applicable to various types of distributors;

- fines, premiums and gifts to distributors;

- conditions to the network, which build distributors;

- exit conditions of distribution and return of the purchased goods to the company warehouse to the distributors;

- terms of office the structure of the distributor in your organization.

In accordance with the compensation plan, building a network of distributors. The distribution network is a hierarchical structure, which is formed as a result of direct distributors attracts new members in the NB. Conditions to the distribution network were the basis for classification of the basic compensation plans. Basic compensation plans there are four main plans: speed, matrix, single-level \& binary [11].

Analysis of the basic compensation plans

Table 1

\begin{tabular}{|c|c|c|c|c|}
\hline Settings & Step & Matrix & Sibling & Binary \\
\hline $\begin{array}{l}\text { The nature } \\
\text { of the consideration }\end{array}$ & $\begin{array}{l}\text { Relative (rewards are } \\
\text { based on the diffe- } \\
\text { rence in grades be- } \\
\text { tween distributors) }\end{array}$ & $\begin{array}{l}\text { The absolute nature } \\
\text { (the reward is calcu- } \\
\text { lated based on the } \\
\text { rank of distributor) }\end{array}$ & $\begin{array}{l}\text { The absolute nature } \\
\text { (the reward is calcula- } \\
\text { ted based on the rank } \\
\text { of distributor) }\end{array}$ & $\begin{array}{l}\text { Relative (rewards are } \\
\text { based on the differ- } \\
\text { ence in grades be- } \\
\text { tween distributors) }\end{array}$ \\
\hline $\begin{array}{l}\text { The limitations } \\
\text { of the network }\end{array}$ & $\begin{array}{l}\text { Not limited to - all is } \\
\text { determined by the dif- } \\
\text { ference in grades }\end{array}$ & $\begin{array}{l}\text { Limited in width and } \\
\text { depth }\end{array}$ & Limited in depth & $\begin{array}{l}\text { Limited in width, not } \\
\text { limited in depth }\end{array}$ \\
\hline $\begin{array}{l}\text { Basis for calculation } \\
\text { of remuneration }\end{array}$ & $\begin{array}{l}\text { The amount of } \\
\text { branches multiplied } \\
\text { by the difference in } \\
\text { discounts (the dis- } \\
\text { tributor, and the dis- } \\
\text { tributor stands at } \\
\text { the head of this } \\
\text { thread) }\end{array}$ & $\begin{array}{l}\text { If the matrix } \\
\text { m(width) x n(depth), } \\
\text { the income obtained } \\
\text { only from the first } n \\
\text { levels, the width } \\
\text { more than m can not } \\
\text { be built }\end{array}$ & $\begin{array}{l}\text { The volume level of } \\
\text { a distributor's organ- } \\
\text { ization, multiplied by } \\
\text { the percentage of this } \\
\text { level that relies on } \\
\text { the compensation } \\
\text { plan }\end{array}$ & $\begin{array}{l}\text { The amount of } \\
\text { branches multiplied } \\
\text { by the difference in } \\
\text { discounts (the dis- } \\
\text { tributor, and the dis- } \\
\text { tributor stands at } \\
\text { the head of this } \\
\text { thread) }\end{array}$ \\
\hline $\begin{array}{l}\text { The direction } \\
\text { of the development } \\
\text { of the UPC }\end{array}$ & Dynamics & Stability & Stability & Dynamics \\
\hline $\begin{array}{l}\text { Ratios of the adja- } \\
\text { cent levels }\end{array}$ & $\begin{array}{l}\text { Increased competi- } \\
\text { tion between neigh- } \\
\text { bouring levels }\end{array}$ & $\begin{array}{l}\text { Not depend on } \\
\text { neighboring levels is } \\
\text { greater than n, sup- } \\
\text { port only encourages } \\
\text { the next levels }\end{array}$ & $\begin{array}{l}\text { Encourages the sup- } \\
\text { port of neighboring } \\
\text { levels }\end{array}$ & $\begin{array}{l}\text { It all depends on } \\
\text { the compensation } \\
\text { plan of the NB }\end{array}$ \\
\hline $\begin{array}{l}\text { The main style } \\
\text { of work }\end{array}$ & Individual & Individual & Command & Command \\
\hline $\begin{array}{l}\text { Employment to } \\
\text { achieve the vertices } \\
\text { of the structure }\end{array}$ & $\begin{array}{l}\text { Only at full employ- } \\
\text { ment }\end{array}$ & $\begin{array}{l}\text { Possible with part- } \\
\text { time employment }\end{array}$ & $\begin{array}{l}\text { Possible with part- } \\
\text { time employment }\end{array}$ & $\begin{array}{l}\text { Only at full } \\
\text { employment }\end{array}$ \\
\hline Social guarantees & The lack of & $\begin{array}{l}\text { The availability of } \\
\text { guarantees only } \\
\text { the top n levels }\end{array}$ & $\begin{array}{l}\text { The presence of } \\
\text { (sometimes exces- } \\
\text { sive warranty) }\end{array}$ & $\begin{array}{l}\text { Warranty only for } \\
\text { large distributors }\end{array}$ \\
\hline Orientation leaders & $\begin{array}{l}\text { Attracting } \\
\text { distributors }\end{array}$ & $\begin{array}{l}\text { No (if someone went } \\
\text { with the first n levels, } \\
\text { it is possible to em- } \\
\text { ploy another in his } \\
\text { place) }\end{array}$ & $\begin{array}{l}\text { Consolidation of } \\
\text { distributors }\end{array}$ & $\begin{array}{l}\text { Attracting } \\
\text { distributors }\end{array}$ \\
\hline
\end{tabular}

In Table 1 of their analysis on the following parameters:

- the nature of the reward (relative - based on the difference of grades distributors, absolute - a given schema); 


\section{Управление в социально-экономических системах}

- lack of structure with which the distributor receives compensation;

- direction of development (continuity, dynamism);

- base of calculation of remuneration;

- ratios of the adjacent levels of the network (mutual aid, competition);

- the main method of working (individual, team);

- employment to reach the vertices of the network (partial, full);

- the presence of "social guarantees" from the NB for distributors (residual income, retirement, etc.);

- activity leaders regarding their structure (inviting new distributors to consolidate and develop the old).

There are hybrid compensation plans: separating.

The first hybrid compensation plan is based on the step of the compensation plan. As a result of separation structure of the leader from the main network, it is transformed into a single-level plan.

The second hybrid compensation plan is based on single-level compensation plan. As a result of separation structure of the leader from the main network it turns into the step plan.

Summing up the analysis of the basic compensation plans, it can be argued that each of them helps to offset lab our costs, i.e. to minimize social risks.

However, none of them takes into account the interests of all the parties functioning fully in various stages of development of the NB for the following reasons [12]:

1. Step and separating the plan does not reflect the dynamics of the organization. In the initial stages (Foundation and concentration) of the NB, it is advisable to interest the beginner of the distributor in attracting new employees and increasing turnover, and in the final stages (inertia and stabilization) leaders in increasing the range of products and services, market expansion, technology deployment, etc. However, the speed and separating the compensation plans do not reflect the considered feature.

2. Matrix and single-level plans are plans with "a heavy bottom", as will help new distributors quickly get income. However, with the growth of the organization incomes of leaders do not grow.

3. Binary plan a plan is "top heavy" as most of the income goes to the few top distributors. The income of an employee is determined by the time of his accession, not the results of his work.

\section{Information-analytical system of project management based}

on complex mathematical models of the functioning of stakeholders

In the implementation of fairly complex large-scale projects and activities in the management of them can simultaneously receive the participation of different stakeholders (stallholder), each of which can have its own project management team headed by a Manager with appropriate credentials and represent the project interests of the parties.

The choice of methods and project management tools is largely determined by which of the stakeholders of the project regarded as the subject of project management in each case. Different stakeholders in the project have different expectations, roles, degree of responsibility and action. This is caused by the following: despite the fact that the project they are partners working for a common result, they may have different goals and interests in the project, different criteria for success and evaluate the achievement of their goals, different values and strategies for achieving goals. These differences significantly affect the formulation of their project objectives, methods, tools and techniques of management tasks, focused on their specific needs.

Recently, in regulatory documents and professional literature (in particular, the research CEMI, RAS ISA and other institutions), more attention is paid to the peculiarities of project management from the perspective of different stakeholders (stakeholders). Most sources are limited to the consideration of this topical issue at a descriptive level [7]. This approach has its limitations and does not solve the problem of increasing the efficiency of the projects. In this issue, there are many unresolved and not researched, which complicates attempts to approach its solution from the practical side.

The main stakeholders include: the investor, the customer, encontacto, gopastami, the project Manager and his team, regulatory authorities, commercial service. For each of them to determine the composition and content of competencies of project management, objectives, tasks, functions, and tools and mechanisms used by them in their activities. The lack of mathematical models adequately describing the tasks and functions of the stakeholders is one of the major constraints in enhancing the effectiveness of project activities at the present stage. 
In [10] an attempt is made to structure the features of key stakeholders and taking them into account to build a new mathematical model of project management. Such models are constructed for investor, customer, project team, key players, suppliers, regulatory authorities and commercial service. Taking into account that in the simulation of the activities of individual stakeholder may be different versions of statements of problems associated with the various modalities of the project. In addition, the methods of implementation of tasks of optimal decision making also have significant multivariate.

In addition, we have developed and described a new class of models, which is a synthesis of generalized network models (with their rich spectrum of resources of equivalent transformations of the models and the description logic-temporal relationships between the elements of the project structure) with probability and alternative models, to a large extent taking into account factors of risk and uncertainty in the implementation of the project. Data model (hereinafter the cyclic alternative network models CASM) are the most flexible and appropriate instrument modeling complexes of discrete operations and describe the process of managing the implementation of difficult or complex project.

CASM have all the advantages of the generalized, probability and alternative models, with their language descriptions are complicated slightly.

Mathematical models of project management for different stakeholders serve as the basis for the design of integrated information-analytical system of management of a difficult project at all stages of its implementation. Describes the structure and functions of the integrated information-analytical system of management of complex project based on the integration and convergence of the multiaspect models of different stakeholders [10].

Information-analytical system of project management based on complex mathematical models of the functioning of the stakeholders allows minimizing the social risks as a result of consideration of the interests of functioning of the parties.

However, for successful implementation of the project to implement the information-analytical system in the modern information society it is necessary to evaluate further the didactic risks associated with the training of stakeholders, i.e. with the formation of the corresponding competences, taking into account their basic education and work experience.

\section{Management of educational trajectories based on the classification of competencies}

Research in the field of education is mainly associated with the quality of training of specialists according to the competences of educational standards. However, the effectiveness of the training system is largely determined by the consideration of basic competencies. In terms of the use of distance learning technologies increases the urgency of the task of planning an educational path for students with various levels of basic education. For example, the basic secondary education of students enrolled at the bachelor's of vocational education can be General, vocational, educational, or vocational teacher.

Traditionally, the planning of the educational trajectory is executed without regard to the basic education of the student or the account is approximately and unreasonable. This situation leads to excessive or insufficient planning of educational material, i.e., there are economic (redundancy) and didactic (failure) threats to the quality of the students.

According to research in the field of vocational teacher education, there is a high percentage of error in the planning of training that requires consideration of the relationship of competences in the design of training, which, in turn, will lead to minimize economic and educational risks [11].

Consideration of interrelation of competences in the design of the training is difficult, because competencies are heterogeneous text information, a set of words that are difficult to analyze. For example, synonyms should be merged into one class, but it is difficult to make due to their different spellings.

In information retrieval systems for working with such information, use its classification by keywords.

A promising direction for research on the relationship of business processes training is a classification of competencies on the objectives, nature, scope of activity and level of education. In [11] provides a classification of competencies to work with information and communication technologies (ICT skills) to prepare students to professionally-pedagogical education (PPE)

ICT competence is a set of competencies, each of which is classified according to the following criteria:

- goal (General, developmental and professional);

- the nature of professional competence objectives (General and special); 


\section{Управление в социально-экономических системах}

- area of activity (educational, professional, research, educational design, etc.);

- education level (vocational, bachelor and master);

- profile of training;

- the specialization.

ICT competence will be denoted in the form: COCP Kucp where

$\mathrm{u}$ - level PPE ( 1 - master of industrial training, 2 - bachelor, 3 - master of vocational training);

$\mathrm{c}$ - target or area of activity ( 1 - secondary, 2 - developing 3 - teaching professional, 4 - research, 5 - educational-design, 6 - organizational and technological, 7 - training of working professions);

$\mathrm{p}$ - profile training $(0-$ for $\mathrm{c}=1$ to $5 ; 1$ - economics and management, 2 - energy, 3 - mechanical engineering and materials processing, 4 - computer science etc.).

ICT - competence is the projection of vector competence for ICT - plane, which is the model of ICT competence. Thus any beam of ICT-plane may be the model of ICT competence of a particular profile of the industry.

Thus, the ICT competence of graduate of PPE determined by the relevant ICT competencies objectives and areas of activities. For example, ICT competence masters professional training profile "Economics and management" will be determined by the formula:

$\mathrm{K}_{\mathrm{M} 01}=\mathrm{K}_{110}+\mathrm{K}_{120}+\mathrm{K}_{130}+\mathrm{K}_{140}+\mathrm{K}_{150}+\mathrm{K}_{141}+\mathrm{K}_{151}+\mathrm{K}_{210}+\mathrm{K}_{220}+\mathrm{K}_{230}+$

$+\mathrm{K}_{240}+\mathrm{K}_{250}+\mathrm{K}_{241}+\mathrm{K}_{251}+\mathrm{K}_{310}+\mathrm{K}_{320}+\mathrm{K}_{330}+\mathrm{K}_{340}+\mathrm{K}_{350}+\mathrm{K}_{341}+\mathrm{K}_{351}$.

For the development of each ICT competencies the student will need to examine the ICT module and perform monitoring activities knowledge, abilities and skills.

Technology planning trajectory information training for students with various levels of basic education is implemented based on the classification of competencies. Basic secondary education of students enrolled at the bachelor's of vocational education can be shared (school), vocational, educational, or vocational teacher PPE. In Table 2 the sign "+" denotes the modules, which can be read to the student taking into account his basic education subject to the fulfillment of the requirements of the final control.

Table 2

Crediting courses modules for information training bachelors PPE at various average basic education

\begin{tabular}{|c|c|c|c|}
\hline \multirow{2}{*}{ Modules } & \multicolumn{3}{|c|}{ Secondary basic education } \\
\cline { 2 - 4 } & Pedagogical & Professional & PPE \\
\hline $\mathrm{M}_{110}$ & - & - & + \\
\hline $\mathrm{M}_{120}$ & - & - & + \\
\hline $\mathrm{M}_{130}$ & + & - & + \\
\hline $\mathrm{M}_{140}$ & + & - & + \\
\hline $\mathrm{M}_{150}$ & + & - & + \\
\hline $\mathrm{M}_{161}$ & - & + & + \\
\hline $\mathrm{M}_{171}$ & - & + & + \\
\hline
\end{tabular}

Basic higher education (bachelor's degree) of students enrolled in the direction of master of vocational education may be vocational, educational, or vocational teacher PPE. In Table 3, the sign "+" denotes the modules, which can be read to the student taking into account his basic education.

The trajectory planning of formation of ICT competence for students with various levels of basic education is based on the following algorithms:

1. For bachelors PPE trajectory of formation of ICT-competence includes the following modules: $\mathrm{M}_{110}-\mathrm{M}_{171}$ и $\mathrm{M}_{210}-\mathrm{M}_{271}$. For students with basic educational, professional or vocational teacher education a number of modules may be offset in accordance with Table 2.

2. For training of masters of PPE trajectory of formation of ICT-competence includes the following modules: $\mathrm{M}_{210}-\mathrm{M}_{271}$ и $\mathrm{M}_{310}-\mathrm{M}_{371}$. For students with basic educational, professional or vocational teacher education a number of modules may be offset in accordance with Table 3.

Method of management of educational trajectories based on the classification of competencies allows us to unambiguously define the path of formation of the competence to prepare graduates with va- 
rious levels of basic education. The method satisfies the didactic principle of security, because it is based on the competence approach and eliminates the threat of insufficient or excessive content of the planned educational material.

Table 3

\section{Crediting courses modules for information training masters of PPE in different upper basic education}

\begin{tabular}{|c|c|c|c|}
\hline \multirow{2}{*}{ Modules } & \multicolumn{3}{|c|}{ Higher basic education } \\
\cline { 2 - 4 } & Pedagogical & Professional & PPE \\
\hline $\mathrm{M}_{210}$ & + & + & + \\
\hline $\mathrm{M}_{220}$ & - & - & + \\
\hline $\mathrm{M}_{230}$ & + & - & + \\
\hline $\mathrm{M}_{240}$ & + & - & + \\
\hline $\mathrm{M}_{250}$ & + & - & + \\
\hline $\mathrm{M}_{261}$ & - & + & + \\
\hline $\mathrm{M}_{271}$ & - & + & + \\
\hline
\end{tabular}

However, for successful implementation of the project for the implementation of this method in modern information society it is necessary to evaluate further the didactic risks associated with the experience of the staff.

\section{Conclusion}

Thus, based on the review of existing methods of project management necessitates a systematic approach to influence risk for three reasons.

First, for the implementation of methods that minimizes economic risks in connection with the registration and processing of a large amount of input information necessary to evaluate the risks of the implementation of information-measuring systems.

Secondly, the implementation of information-analytical systems and compensation plans to reduce social risks, it is necessary to consider the risks, considering the dynamics of the development of enterprises.

Thirdly, to implement the method of management of educational trajectories on the basis of classification of competences, allowing minimizing the didactic risks, it is necessary to consider the risks based on the experience of the staff.

\section{References}

1. EC (2000). Communication from the Commission: E-Learning - Designing "Tejas at Niit" Tomorrow's Education. Brussels: European Commission.

2. Umnyye lyudi, umnyye goroda: chto nado znat' o programme razvitiya tsifrovoy ekonomiki [Smart People, Smart City: What You Need to Know about the Program of Development of the Digital Economy]. Available at: http://tass.ru/ekonomika/4306382.

3. Tolmachev V.D. [On the Staffing of Modern Energy]. Energy Security and Energy Saving, 2011, no. 1 , pp. 37-38. (in Russ.)

4. Pels D. PM World Journal. Vol. II, Issue XII - December, 2013. Available at: www.pmworldjournal.net.

5. Mokeev V.V. Metod glavnykh komponent i metod sobstvennykh sostoyaniy $v$ zadachakh analiza $i$ prognozirovaniya: monografiya [The Method of Principal Components and the Method of Eigenstates in Analysis and Forecasting Problems: Monograph]. Chelyabinsk, South Ural St. Univ. Publ., 2014. $138 \mathrm{p}$.

6. Pazderin A.V., Sofin V.V., Samoylenko V.O. [The Mathematical Method of Monitoring of the Reliability of the Measuring Information about the Flow of Energy Resources on the Basis of the Theory of State]. Heat Power Engineering, 2015, no. 11, pp. 26-31. (in Russ.)

7. Young, T.L. Successful Project Management. London, Kogan Page Ltd., 2006. 


\title{
Управление в социально-экономических системах
}

8. Artemova O.V. Stabilizatsiya i ekonomicheskiy rost v usloviyakh tsiklichnosti (makroekonomicheskiy podkhod): Monografiya [Stabilization and Economic Growth in a Cyclical Environment (Macroeconomic Approach): Monograph]. Chelyabinsk, 2002. 296 p.

9. Gnatyshina E.A., Bogatenkov S.A., Gnatyshina E.V., Uvarina N.V. Informatsionnaya podgotovka pedagogov professional'nogo obucheniya $v$ aspekte bezopasnosti [Information Training of Teachers of Professional Training in the Aspect of Safety]. Chelyabinsk, Chelyab. State. Ped. Univ. Publ., 2015. 415 p.

10. Gel'rud Ya.D., Loginovskiy O.V. Upravlenie proektami: metody, modeli, sistemy: monografiya [Project Management: Methods, Models, Systems: Monograph]. South Ural St. Univ. Publ., 2015, 330 p.

11. Podrobnyy analiz naiboleye populyarnykh kompensatsionnykh planov, primenyayemykh segodnya [A Detailed Analysis of the Most Popular Compensation Plans Used Today]. Available at: http://www.oksoft.ru/marketing_planes_analytic.

12. Bogatenkov D.S. [Managing of the Activities of a Networked Commercial Enterprise in the Region]. Prospects of Science, 2010, no. 8 (10), pp. 72-76. (in Russ.)

Received 6 December 2017

Удк 681.519.3

DOI: $10.14529 /$ ctcr180111

\section{АНАЛИЗ МЕТОДОВ УПРАВЛЕНИЯ ПРОЕКТАМИ В АСПЕКТЕ БЕЗОПАСНОСТИ}

\author{
С.А. Богатенков ${ }^{1}$, Я.Д. Гельруд ${ }^{1}$, Д.С. Богатенков ${ }^{2}$ \\ ${ }^{1}$ Южно-Уральский государственный университет, г. Челябинск, Россия, \\ 2 Челябинский государственный университет, г. Челябинск, Россия
}

\begin{abstract}
Современное информационное общество характеризуется интенсивным проникновением информационных технологий (ИТ) во все сферы жизни. Современные социально-экономические системы находятся в постоянной эволюции, увеличивая их сложность и количество показателей, необходимых для анализа. Проблема техногенной энергетической безопасности на 70 \% связана с человеческим фактором. Современное информационное общество характеризуется повышенными рисками. Ущерб от технологических катастроф, несчастных случаев соизмерим с годовым ростом ВВП. Информационно-аналитическая система управления проектами на основе сложных математических моделей функционирования заинтересованных сторон позволяет минимизировать социальные риски в результате системного рассмотрения их интересов. Однако для успешной реализации проекта по внедрению информационноаналитической системы в современном информационном обществе необходимо дополнительно оценить дидактические риски, связанные с обучением заинтересованных сторон, то есть с формированием соответствующих компетенций, с учетом их образования и опыта работы. Увеличение числа показателей социально-экономических систем и роли человеческого фактора приводит к увеличению риска и количеству неудачных проектов. Основываясь на обзоре руководства проектом, авторы пришли к выводу о необходимости системного подхода к воздействию рисков. Во-первых, для внедрения методов, которые минимизируют экономические риски в связи с регистрацией и обработкой большого количества исходной информации, необходимой для оценки рисков внедрения информационно-измерительных систем. Во-вторых, при внедрении информационно-аналитических систем и компенсационных планов по снижению социальных рисков необходимо учитывать риски, вытекающие из динамики развития предприятий. В-третьих, для реализации метода управления образовательными траекториями на основе классификации компетенций, позволяющего минимизировать дидактические риски, необходимо учитывать риски, основанные на опыте персонала.

Ключевые слова: управление проектами, методы, безопасность, риск.
\end{abstract}




\section{Лumepamypa}

1. EC (2000). Communication from the Commission: E-Learning - Designing "Tejas at Niit" Tomorrow's Education. Brussels: European Commission.

2. Умные люди, умный город: что вам нужно знать о программе развития иифровой экономики. - http://tass.ru/ekonomika/4306382.

3. Толмачев, В.Д. О кадровом обеспечении современной энергетики/ В.Д. Толмачев // Энергобезопасность и энергосбережение. - 2011. - № 1. - C. 37-38.

4. Pels D. PM World Journal. Vol. II, Issue XII-December. 2013. - www.pmworldjournal.net.

5. Мокеев, В.В. Метод основных компонентов и метод собственных состояний в задачах анализа и прогнозирования: моногр. / В.В. Мокеев. - Челябинск: Издат. иентр ЮУрГУ, 2014. $138 \mathrm{c}$.

6. Паздерин, А.В. Математический метод мониторинга достоверности измерительной информации о потоке энергетических ресурсов на основе теории оченки состояния / А.В. Паздерин, В.В. Софин, В.О. Самойленко // Тепловая энергетика. - 2015. - № 11. - С. 26-31.

7. Young, T.L. Successful Project Management / T.L. Young. - London: Kogan Page Ltd., 2006.

8. Артемова, О.В. Стабилизация и экономический рост в ииклической среде (макроэкономический подход): моногр. / О.В. Артемова. - Челябинск, 2002. - 296 с.

9. Информационная подготовка преподавателей в аспекте безопасности / Е.А. Гнатышина, С.А. Богатенков, Е.В. Гнатышина, Н.В. Уварина. - Челябинск: Изд-во ЧГПУ, 2015. - 415 c.

10. Гельруд, Я.Д. Управление проектами: методы, модели, системы: моногр. / Я.Д. Гельруд, О.В. Логиновский. - Издат. иентр ЮУрГУ, 2015. - 330 c.

11. Подробный анализ наиболее популярных компенсаиионных планов, используемых сегодня. http://www.oksoft.ru/marketing_planes_analytic.

12. Богатенков, Д.С. Управление деятельностью сетевого коммерческого предприятия в регионе / Д.С. Богатенков // Перспективы науки. - 2010. - № 8 (10). - С. 72-76.

Богатенков Сергей Александрович, канд. техн. наук, доцент кафедры информационных технологий в экономике, Южно-Уральский государственный университет, г. Челябинск; ser-bogatenkov@yandex.ru.

Гельруд Яков Давидович, д-р техн. наук, профессор кафедры информационно-аналитического обеспечения управления в социально-экономических системах, Южно-Уральский государственный университет, г. Челябинск; gelrud@mail.ru.

Богатенков Дмитрий Сергеевич, канд. экон. наук, доцент кафедры информационных технологий и экономической информатики, Челябинский государственный университет, г. Челябинск; mr.bogatenkov@gmail.com.

Поступила в редакцию 6 декабря 20172.

\section{ОБРАЗЕЦ ЦИТИРОВАНИЯ}

Bogatenkov, S.A. Analysis of Methods of Project Management in Aspect of Security / S.A. Bogatenkov, Ya.D. Gel'rud, D.S. Bogatenkov // Вестник ЮУрГУ. Серия «Компьютерные технологии, управление, радиоэлектроника». - 2018. - Т. 18, № 1. - С. 96-105. DOI: $10.14529 /$ ctcr 180111

\section{FOR CITATION}

Bogatenkov S.A., Gel'rud Ya.D., Bogatenkov D.S. Analysis of Methods of Project Management in Aspect of Security. Bulletin of the South Ural State University. Ser. Computer Technologies, Automatic Control, Radio Electronics, 2018, vol. 18, no. 1, pp. 96-105. DOI: $10.14529 /$ ctcr 180111 